\title{
GH replacement in adults: interactions with other pituitary hormone deficiencies and replacement therapies
}

\author{
Helena Filipsson and Gudmundur Johannsson \\ Department of Endocrinology, Sahlgrenska Academy, Sahlgrenska University Hospital, Gothenburg University, SE-413 45 Gothenburg, Sweden \\ (Correspondence should be addressed to G Johannsson; Email: gudmundur.johannsson@gu.se)
}

\begin{abstract}
Severe GH deficiency (GHD) in adults has been described as a clinical entity. However, some of the features associated with GHD could be due to unphysiological and inadequate replacement of other pituitary hormone deficiencies. This may be true for glucocorticoid replacement that lacks a biomarker making dose titration and monitoring difficult. Moreover, oral estrogen replacement therapy decreases IGF1 levels compared with the transdermal route, which attenuates the responsiveness to GH replacement therapy in women. In addition, in untreated female hypogonadism, oral estrogen may augment the features associated with GHD in adult women. Important interactions between the hormones used for replacing pituitary hormone deficiency occur. Introducing GH replacement may unmask both an incipient adrenal insufficiency and central hypothyroidism. Therefore, awareness and proper monitoring of these hormonal interactions are important in order to reach an optimal replacement therapy. This review will focus on the complex hormonal interactions between GH and other pituitary hormones in GHD and in GH replacement.
\end{abstract}

European Journal of Endocrinology 161 S85-S95

\section{Introduction}

Hypopituitarism acquired in adult life is often a result of pituitary or peripituitary tumors and their treatment (1-3), most frequently represented by a nonfunctioning pituitary adenoma $(4,5)$. In a large study (6), the prevalence of hypopituitarism from pituitary tumors was 28/100 000 with nontumor origin of hypopituitarism representing $\sim 30 \%$ of the cases.

The history of hormonal replacement of hypopituitarism started during the 19th century, as desiccated thyroid hormone became available in 1891. During the third decade of the 20th century, the discovery and purification of sexual steroids emerged (7); in the mid-20th century, the first reports of glucocorticoid (GC) replacement were published; and the first placebo-controlled trials of growth hormone (GH) replacement therapy in adults were published in $1989(8,9)$ after recombinant human GH became available (1).

With the availability of recombinant human $\mathrm{GH}$ treatment, the use in severe GH deficiency (GHD) in childhood was possible and enhanced the interest of possible consequences of GHD in adults. The

This paper forms part of a special issue on $\mathrm{KIMS}^{\circledR}$ and ACROSTUDY $^{\mathrm{TM}}$. Pfizer Inc. has supported the publication of this special issue. first data of excess mortality in adult hypopituitary patients receiving conventional replacement therapy with unreplaced GHD were reported in 1990 (10). Further data have confirmed that hypopituitary patients have excess cardiovascular and cerebrovascular mortality (5, 10-12), which has been designated to untreated GHD or the treatment modalities of the underlying pituitary disease, such as cranial irradiation (5).

Mortality data from long-term GH replacement therapy from controlled trials are as yet unavailable; a positive outcome of GH replacement is indicated by a study (13) in which the morbidity in myocardial infarction, cerebrovascular disease, and malignancies was increased in untreated GHD patients, but was similar or lower than that of the normal population in patients receiving $\mathrm{GH}$ replacement. Although these data support the impact of GH on outcome in hypopituitary patients, further supportive data are needed before the impact of GH replacement on morbidity and mortality remains to be proven.

The clinical efforts made to define and replace GHD in adults have put focus on hypopituitarism in general. The impact of other replacement therapies with GC, thyroxine $\left(\mathrm{T}_{4}\right)$, and sex steroids on the clinical features of hypopituitarism and their interactions with GHD and GH replacement has, therefore, been studied. These therapies do not completely mirror 
endogenous hormonal production and their monitoring is also made difficult by the lack of good biomarkers of their action. This review will focus on the impact of GC, thyroid hormone, and sex steroid hormone deficiency and their treatments on clinical features associated with adult GHD.

\section{Adult GHD}

The clinical features associated with adult GHD are abdominal obesity, decreased lean body mass (LBM), reduced muscle strength and exercise capacity, increased serum concentration of low-density lipoprotein cholesterol (LDL-C) and C-reactive protein (CRP), reduced bone mineral density (BMD), dry skin, and impaired psychological well being $(1,14,15)$.

The efficacy of GH treatment was initially evaluated in short-term-controlled studies with improvement in body composition, lipids, and quality of life (QoL) (16). These results are also found in long-term studies (17-20) with a reduction in total body fat and a progressive improvement of total- and LDL-C. After an initial deterioration, $\mathrm{HbAlc}$ decreases progressively (17). In addition, muscle mass and LBM increase and muscle strength improves, at least during the first 5 years of treatment $(18,20)$. Improvement in QoL occurs, predominantly, during the first year of $\mathrm{GH}$ treatment, but a successive improvement is observed $(19,21)$ and after 8 years of GH treatment, the GHD patients have attained the same QoL score as the normal population (19). All these data support the importance of GHD per se for the phenotype described above of the adult GHD patient. However, it should be remembered that most patients being replaced with GH in the GHD trials have had multiple pituitary hormone deficiencies (MPHD) and, therefore, the impact of those on the baseline status cannot be excluded.

\section{Differences between isolated GHD and multiple hormonal deficiencies}

The influence of other hormonal replacement therapies than GH on the clinical features of GHD and its outcome may be judged from the studies comparing patients with isolated GHD (IGHD) and MPHD. This type of comparison was performed using the Pfizer International Metabolic Database (KIMS) with 274 patients with IGHD and 2594 patients with MPHD (22). The study was unable to detect differences in serum lipid levels, glucose metabolism, fracture rate, and QoL among the two groups of patients. As no major differences were detected between patients with IGHD and MPHD, the concept that the clinical phenotype linked to severe GHD adults is largely unaffected by other hormonal replacement therapies was strengthened. However, a large pharmaco-epidemiological study may be affected by a selection bias of those patients included. Moreover, the criteria for $\mathrm{GH}$ replacement therapy are different in different countries, and finally some patients classified with severe IGHD may have other partial hormonal deficiencies, yet to be detected, that may influence the results. Therefore, it is not possible to exclude that the doses and the regime we use to replace GC, $\mathrm{T}_{4}$, and sex steroids is influencing the outcome of patients with MPHD.

\section{GHD testing and other pituitary hormone deficiencies}

The levels of serum insulin-like growth factor 1 (IGF1) are not a sensitive test for GHD in adults unless the patient has three or more pituitary hormone deficiencies and a serum IGF1 concentration below the normal reference range (23). Otherwise, a GH stimulation test needs to be performed. The current guidelines on the diagnosis of GHD advocate that other hormonal deficiencies shall be adequately replaced before any GH testing (23).

This is based on the knowledge of other hormones that affect the tests used for GHD. Short-term deprivation of hydrocortisone (HC) therapy does not, but chronic hypocortisolism does impair GH secretion (within normal range $>15 \mu \mathrm{g} / \mathrm{l}$ ) (24). Also, GH testing in patients suffering from acute stress or in patients receiving high doses of GC should be avoided, as there are indications that the $\mathrm{GH}$ response to stimulations tests such as the pyridostigmine (PD)-GHRH is reduced (25). In Cushing's syndrome, it is well known that the recovery of GH secretion occurs only after long-term correction of hypercortisolism (26).

Moreover, serum IGF1 levels are reduced in patients with central hypothyroidism (27) and GH stimulation with insulin tolerance test (ITT) (28), or GHRH (29) is blunted in hypothyroidism and restored after adequate $\mathrm{T}_{4}$ replacement. In hyperthyroidism, IGF1 is reported to be normal or elevated $(30,31)$. Also, hyperthyroid patients have a normal GH response to GH-releasing peptide 6 together with a blunted GH responsiveness to GHRH $(32,33)$.

Hypogonadism also affects the GH secretion. Oral estrogens reduce serum IGF1 levels more than transdermal estrogens (see under heading central hypogonadism). In a study of premenauposal women studied before and after ovariectomy, the response to GHRH was reduced in hypogonadism and restored back to normal levels after transdermal estrogen replacement (34). In men with primary hypogonadism, IGF1 levels were lower than in healthy controls and were restored after testosterone replacement (35).

Furthermore, prolactin deficiency is independently associated with reduced IGF1 in GHD patients (36), and there are reports that hyperprolactinemia in nonfunctioning pituitary adenomas reduces the $\mathrm{GH}$ response to 
GHRH but not to an ITT (37). In summary, management of other pituitary hormone deficiencies is needed in order to be able to adequately perform and interpret a diagnostic procedure for GHD.

\section{Adrenocorticoid axis}

The association between excess GC and abdominal obesity, reduced LBM and BMC, and glucose intolerance is well recognized in patients with all forms of Cushing's syndrome. In GHD and obesity, there is an increased local 11 $\beta$-hydroxysteroid dehydrogenase (HSD) type 1 activity in adipose tissues (38-41) resulting in increased local cortisol exposure (38) (Fig. 1). This is reduced after $\mathrm{GH}$ replacement $(42,43)$ possibly explaining some of the metabolic features associated with hypopituitarism and severe GHD and the beneficial effects of GH therapy.

The aims of GC replacement therapy are to mimic the circadian serum steroid profile, to respond to the increased need for cortisol during physical and physiological stimulation, and to achieve normal well being, normal metabolism, and favourable long-term outcome (3), avoiding under- (44) and overreplacement $(45,46)$.

The outcome of GC replacement therapy has been considered satisfactory (47) until recently. Patients with hypopituitarism have double the standardized mortality rate $(\mathrm{SMR})(5,10)$, and young adults with hypopituitarism and concomitant adrenal insufficiency have more than sevenfold the expected mortality rate (48). Moreover, patients with Addison's disease have also been shown to have more than double the $\operatorname{SMR}(49,50)$. A possible explanation for this increased mortality rate is an inappropriate GC replacement therapy; that is, both too high maintenance doses and an inadequate GC exposure in response to stress and concurrent illnesses.

$11 \beta$-hydroxysteroid dehydrogenase (11 $\beta$-HSD) type 1 activity

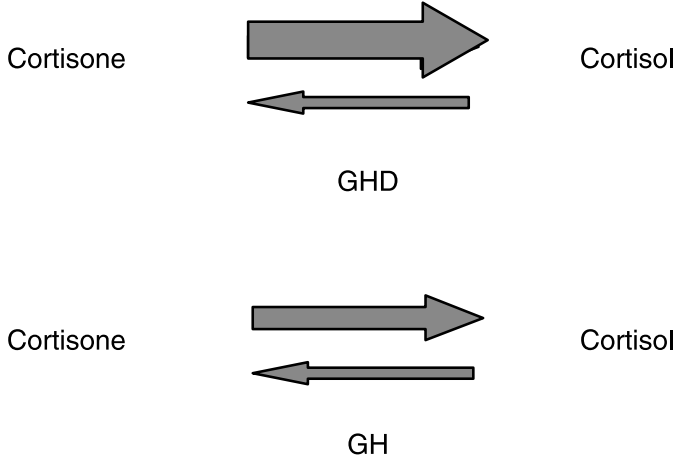

Figure 1 The $11 \beta$-HSD type 1 enzyme activity is enhanced in $\mathrm{GH}$ deficiency (GHD), thus exposing the tissues to more cortisol, whereas $\mathrm{GH}$ replacement inhibits the type 1 shuttle.
The daily doses of GC used for replacement therapy are being reduced during the last 10 years, as the daily cortisol production rate is substantially lower than previously thought $(51,52)$. The estimated daily cortisol production rate in normal subjects has been found to be between 9 and $11 \mathrm{mg} / \mathrm{m}^{2}$ per day (corresponding to $\sim 15.5-19 \mathrm{mg} /$ day in an average adult subject) (52). The previously recommended dose of $30 \mathrm{mg} /$ day of $\mathrm{HC}$ is, therefore, probably too high for most patients with adrenal insufficiency (53). This is supported by studies that have been able to reduce most patients to $20 \mathrm{mg} \mathrm{HC}$ or $25 \mathrm{mg}$ cortisone acetate by individual dose titrations (54-56).

The effect of GC replacement therapy on bone metabolism and cardiovascular risk factors has been assessed (57). Zelissen et al. (58) found an inverse correlation between lumbar spine BMD and increasing dose of $\mathrm{HC} / \mathrm{kg}$ body weight in men with Addison's disease, but not in women. Wichers et al. (59) conducted a randomized study in nine patients with ACTH insufficiency who were treated for three periods of 2 weeks with 15,20 , or $30 \mathrm{mg}$ /day of HC. Serum levels of osteocalcin, as a marker of bone formation, reduced with increasing doses of $\mathrm{HC}$, but resorption markers remained unchanged. Al-Shoumer et al. (60) reported that hypopituitary patients on GC replacement were more insulin resistant in the mornings when $\mathrm{HC}$ was administered than in the mornings when no $\mathrm{HC}$ was given. In contrast, Dunne et al. (61) found no significant difference in blood pressure and glucose metabolism over a 3-month period when reducing the daily dose of HC from 30 to $15 \mathrm{mg}$. This is in accordance with a report from McConnell et al. (62) who found glucose metabolism to be similar in 15 ACTH-insufficient patients who, in a randomized cross-over study, received either i.v. HC, in order to mimic the physiological serum cortisol profile, or $15+5 \mathrm{mg} \mathrm{HC}$ administered orally. In contrast to the above studies, 11 panhypopituitary patients with untreated GHD in an open noncontrolled study were instructed to reduce their dose from 20 to $30 \mathrm{mg} \mathrm{HC} /$ day at baseline to $10-15 \mathrm{mg} /$ day (63). After 6-12 months, body weight, total and abdominal body fat mass, total cholesterol, and triglycerides had decreased and QoL score was improved.

The metabolic effects of different doses of GC for replacement therapy were studied in a large study of more than 2000 patients (4). A significant GC doseresponse relationship was demonstrated with waist circumference, serum triglyceride concentration, totaland LDL-C levels, and body mass index (BMI; Fig. 2A-D). Of interest was that patients receiving $\mathrm{HC}$ equivalent doses of $<20 \mathrm{mg}$ /day had a similar metabolic profile to those with an intact hypothalamuspituitary-adrenal axis. This study is, therefore, the first to demonstrate that a mean HC equivalent replacement dose $\geq 20 \mathrm{mg}$ augments the metabolic perturbations associated with hypopituitarism and untreated GHD. 
A Mean waist circumference in $\mathrm{cm}$ at baseline with $95 \% \mathrm{Cl}$ by $\mathrm{HC}$ equivalent dose category (adjustment for age, sex and country)

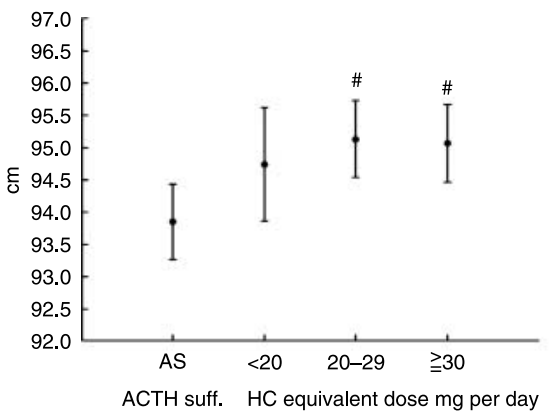

C
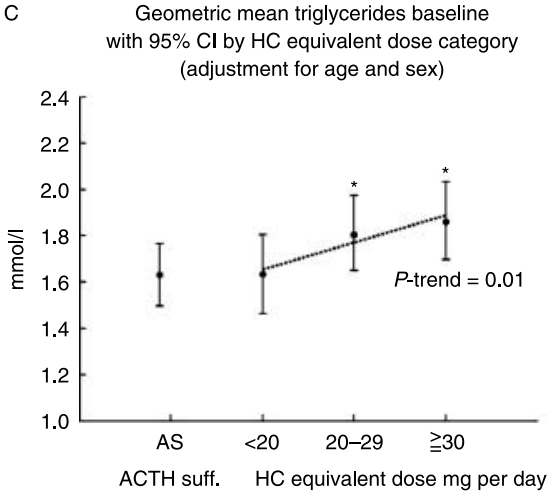

B Mean total cholesterol with $95 \% \mathrm{Cl}$ by $\mathrm{HC}$ equivalent dose category (adjustment for age and sex)

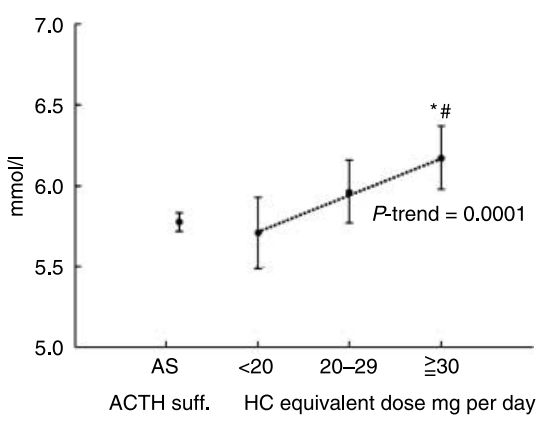

D Mean LDL cholesterol with $95 \% \mathrm{Cl}$ by $\mathrm{HC}$ equivalent dose category (adjustment for age and sex)

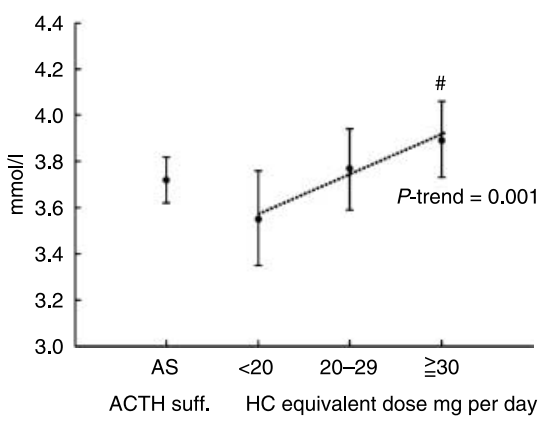

Figure 2 Hydrocortisone $(\mathrm{HC})$ equivalent dose categories in ACTH-deficient and ACTH-sufficient patients with GHD before $\mathrm{GH}$ replacement. The broken line represents a dose-response analysis within the glucocorticoid-treated groups.

(A) Waist, ${ }^{\#} P<0.001$ versus AS; (B) total cholesterol, ${ }^{*} P<0.0001$ versus AS, ${ }^{\#} P<0.0001$ vs $<20 \mathrm{mg} / \mathrm{day}$; (C) triglycerides logarithmic transformed, ${ }^{*} P<0.001$ versus AS; (D) LDL cholesterol, ${ }^{\#} P<0.05$ vs $<20 \mathrm{mg} /$ day. Published in Journal of Clinical Endocrinology and Metabolism 200691 3954-3961. Reproduced with permission of The Endocrine Society (4).
These metabolic associations with GC doses remained after 1 year of $\mathrm{GH}$ treatment.

However, it is of some surprise in this large cohort of subjects that the relationship between these factors and the dose of GC was not stronger, indicating that other endocrine insufficiencies may have strong modulating effects and attenuate some of the differences between the ACTH-deficient and the sufficient patients. It is also possible that increased tissue exposure of cortisol, as a result of increased $11 \beta$-HSD type 1 activity occurring in both ACTH-deficient and replete GHD subjects, may exert a major influence over and above that resulting from different exogenous GC dose. The most common daily dose of $\mathrm{HC}$ in the study was $30 \mathrm{mg}$. The study, therefore, clearly indicates that lower doses are advocated for the use of replacement therapy in patients with secondary adrenal insufficiency.

Recent studies have demonstrated that well being and QoL are compromised in patients with both primary and secondary AI (64-66). Of interest is that the pattern of deficit according to the questionnaires used is similar among patients with primary adrenal insufficiency and those with hypopituitarism, indicating that a common denominator for this might be the quality of the GC replacement. In a recent study using a subcutaneous infusion pump to re-establish the physiological circadian rhythm of cortisol, patients were able to reduce their total daily doses while experiencing improved levels of subjective health and well being (67). It is, therefore, likely that the pattern of HC delivery and the total plasma cortisol exposure profile are of importance for patient outcome in both primary and secondary adrenal insufficiency.

\section{Central hypothyroidism}

It is possible that untreated mild $\mathrm{CH}$ or poorly replaced $\mathrm{CH}$ can have clinical features that are associated with severe GHD.

In $\mathrm{CH}$, the bioactivity of TSH (68) is reduced because of inadequate hypothalamic stimulation that causes the pituitary to secrete abnormally glycosylated TSH. TSH in this form has a longer half-life than normal TSH (69), which explains the normal and sometimes slightly elevated levels of TSH seen in $\mathrm{CH}$ (70). Using reduced levels of TSH for the diagnosis of $\mathrm{CH}$ is, therefore, not useful.

In $\mathrm{CH}$, reduced serum $\mathrm{T}_{4}$ level is the single best criterion for diagnosis. In mild $\mathrm{CH}$, thyroid hormone levels may, however, be within the lower normal range (71-74). In addition, diagnosing partial $\mathrm{CH}$ may be blurred by the $25 \%$ intra-individual variation of free $\mathrm{T}_{4}$ $\left(\mathrm{FT}_{4}\right)(71)$, which also suggests that $\mathrm{CH}$ cases are found when thyroid hormone levels are in the lower parts of the reference range. Therefore, a decrease of $\mathrm{FT}_{4}>20 \%$ in a patient with pituitary disease is indicative of $\mathrm{CH}(75)$. 
The diagnosis of $\mathrm{CH}$ is, therefore, in many cases not straightforward. Patients with nonthyroidal illness (NTI) may have values that overlap with those of $\mathrm{CH}$. Therefore, analyses should be repeated and evaluated in the light of the clinical situation. A clue to distinguishing these two conditions is the evaluation of triiodothyronine $\left(\mathrm{T}_{3}\right)(76,77)$.

GH replacement increases conversion of $\mathrm{T}_{4}$ to $\mathrm{T}_{3}$ and decreases that of $\mathrm{T}_{4}$ to reversed $\mathrm{T}_{3}(9,78,79)$. Therefore, careful monitoring of thyroid function is mandatory during GH treatment (78), as it may indicate changes in the $\mathrm{T}_{4}$ dose needed. Patients with untreated GHD may have higher $\mathrm{FT}_{4}$ levels than on $\mathrm{GH}$ replacement; $\mathrm{GH}$ therapy may, therefore, unmask undiagnosed $\mathrm{CH}$ (74, $79,80)$. This effect is also seen in children with MHPD, but not in children with IGHD (81). The same mechanism may induce high $\mathrm{FT}_{4}$ in a previously wellreplaced patient when $\mathrm{GH}$ treatment is started (80). Also to be considered is that both transdermal and oral estrogens increase thyroxin-binding globulin and patients may need higher $\mathrm{L}_{-} \mathrm{T}_{4}$ replacement doses when these therapies are combined (75).

In addition, the thyroid hormonal system in hypopituitary patients is influenced by GC replacement (82). GCs seem to reduce the conversion of $\mathrm{T}_{4}$ to $\mathrm{T}_{3}$, which may have an impact in patients on overly high dose of HC. Also, induction of GC replacement may unmask an undiagnosed $\mathrm{CH}$. Moreover, it is a well-known clinical concept that evaluation of the adrenal axis is mandatory before initiating $\mathrm{T}_{4}$ replacement, as it otherwise may trigger an adrenal crisis in patients with untreated adrenal insufficiency by accelerating the metabolism of cortisol (83) and increasing the metabolic rate.

Because of the uncertainty of using basal thyroid hormone levels in the evaluation of $\mathrm{CH}$, other tests have been developed. Patients with $\mathrm{CH}$ have a blunted nocturnal surge $(84,85)$ in TSH circadian secretion (86-88). However, this may be found in NTI (89), in post-operative patients $(90,91)$, during starvation (92), and in severe primary hypothyroidism (93). The TRH stimulation test is used in the diagnosis of $\mathrm{CH}(94,95)$, but its value has been questioned $(96,97)$. In addition, in some early studies, bovine TSH stimulation was considered for the diagnosis of $\mathrm{CH}(98,99)$, but its use was terminated due to commonly occurring allergic reactions (100). Recently, the use of recombinant human TSH (rhTSH) as a diagnostic tool in $\mathrm{CH}$ has been studied. Patients with newly diagnosed $\mathrm{CH}$ and no previous $\mathrm{T}_{4}$ treatment exhibited a less pronounced increase in thyroid hormone levels after administration of $0.9 \mathrm{mg}$ rhTSH than controls (Fig. 3). The usefulness of rhTSH for the diagnosis of $\mathrm{CH}$ remains to be proven.

Monitoring serum TSH level for judging an appropriate $\mathrm{T}_{4}$ replacement level in $\mathrm{CH}$ is not useful, making $\mathrm{T}_{4}$ replacement more arbitrary and increasing the risks of both under- and overreplacement. This could result in consequences similar to those described for both subclinical hypo- and hyperthyroidism (101-107).

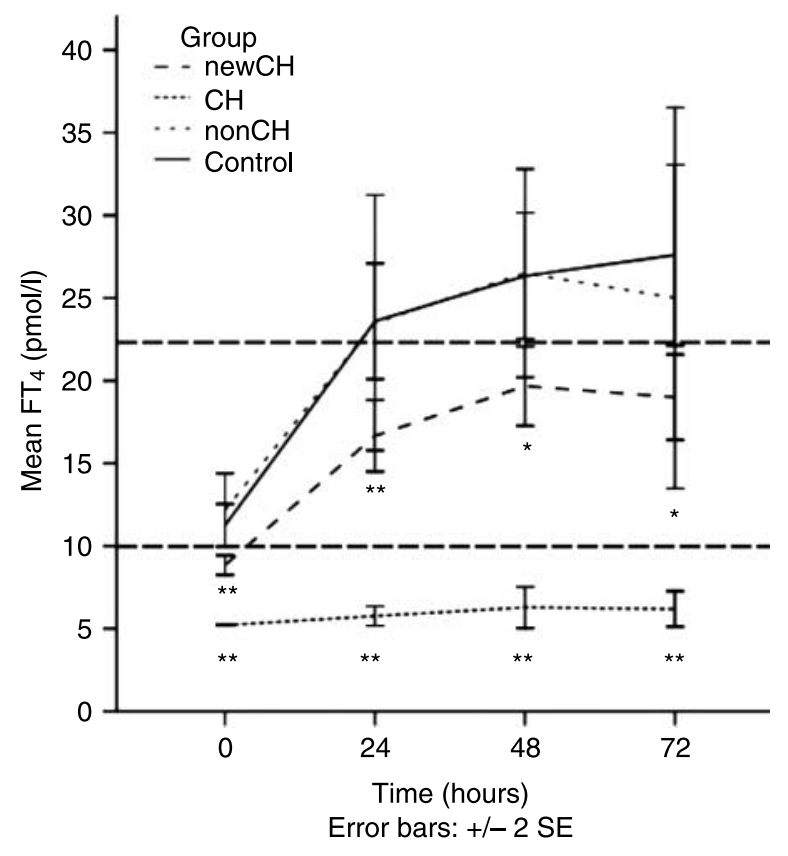

Figure 3 The figure shows the high-dose rhTSH response $(0.9 \mathrm{mg}$ i.m.) in six patients with previous treated central hypothyroidism $(\mathrm{CH})$, six newly diagnosed $\mathrm{CH}$ (newCH), six patients with hypopituitarism without $\mathrm{CH}$ (nonCH), and six healthy controls in $\mathrm{FT}_{4} .{ }^{\star} P<0.05,{ }^{\star \star} P<0.01$ newCH- or $\mathrm{CH}$ group versus controls. Values are mean. Error bars =S.E.M. The horizontal broken lines represent normal range. Published in European Journal of Endocrinology 2008159 153-160. Reproduced with permission of the European Society of Endocrinology.

In children with documented mild $\mathrm{CH}$ and short stature, increasing serum $\mathrm{FT}_{4}$ from the lower third to near the upper third of the normal reference interval during 6 months significantly increases growth velocity (108). Thus, minor thyroid dysfunction may have detrimental effects on patient outcome.

Recommendations for adequate $\mathrm{T}_{4}$ replacement in adult patients with $\mathrm{CH}$ are based on a few reports $(75$, $77,109-111)$ that direct dosing by weight, TSH and $\mathrm{FT}_{4}$ levels. In 1999, Ferretti et al. (77) describe a mean dose of $\mathrm{T}_{4}$ of $1.5 \pm 0.3 \mu \mathrm{g} / \mathrm{kg}$ body weight that is modified according to age, targeting normal free $\mathrm{T}_{3}$ without signs of overreplacement. Alexopoulou et al. (75) used a mean dose of $1.6 \pm 0.5 \mu \mathrm{g} / \mathrm{kg}$ body weight/ day resulting in suppressed TSH in $75 \%$ of patients, and Shimon et al. (110) observed a suppression of TSH below $0.1 \mathrm{mU} / \mathrm{l}$ predicting euthyroidism in $92 \%$ of cases, rather than $34 \%$ when TSH was $>1 \mathrm{mU} / \mathrm{l}$. Finally, Carrozza et al. (109) recommended $\mathrm{FT}_{4}$ to be in the mid-normal or in the upper part of the reference range, which was supported in another study (111). In this study, it was observed that $\mathrm{CH}$ patients on empirical $\mathrm{T}_{4}$ doses $(1 \pm 0.05 \mu \mathrm{g} / \mathrm{kg}$ per day) had worse outcome in terms of BMI, total-, LDL-, and HDL-cholesterol than patients on a body weight-guided dosing $(1.6 \mu \mathrm{g} / \mathrm{kg}$ per day) (111). 
The above dose titration studies, therefore, suggest that $\mathrm{FT}_{4}$ should be in the upper range of normal, TSH levels should be below $0.1 \mathrm{mIU} / \mathrm{l}$ using modern sensitive assays, and the dose of $\mathrm{L}^{-} \mathrm{T}_{4}$ should be targeted at $\sim 1.6 \mu \mathrm{g} / \mathrm{kg}$ per day meaning $112 \mu \mathrm{g}$ per day for a $70 \mathrm{~kg}$ person. To what extent these recommendations are being used is not known and, most importantly, the outcome of various dose exposure of $\mathrm{L}-\mathrm{T}_{4}$ in hypopituitary patients remains to be determined. This is an important piece of information in the light of the impact subclinical hypoand hyperthyroidism have on outcome $(101,105,107)$.

\section{Central hypogonadism}

There are some well-recognized interactions between the GH-IGF1 axis and sex steroids. These interactions seem to play a role in the treatment of hypopituitarism. Whether current therapy of sex steroid replacement therapy affects the clinical consequences of hypopituitarism and affects the phenotype of severe GHD is less well known, except for the impact of oral route of estrogen replacement on metabolism on hypopituitary women. Moreover, there are also indications that untreated hypogonadism in women may explain to some extent their increased cardiovascular mortality (5).

There is a first pass hepatic effect of oral estradiol that results in lowering of serum IGF1 in both healthy and GHD women (112). Serum IGF1 in the GH-deficient state is lowered further by oral estrogen, but unaffected by transdermal therapy (113). This observation may explain why some investigators have observed IGF1 levels to be lower in hypopituitary women than men, despite having a similar degree of impaired $\mathrm{GH}$ responses to insulin-induced hypoglycemia (114). Women with hypopituitarism may be more susceptible to the hepatic effects of oral estrogen administration because of the loss of feedback GH response. The level and degree of IGF1 suppression are greater in GH-deficient women than post-menopausal (GH-sufficient hypogonadal) women in response to oral estrogen treatment (115). Cook et al. observed that $\mathrm{GH}$ requirements in men were not different from those in women not taking estrogens, but that women taking oral estrogens required at least a twofold greater dosage of GH (116).

Wolthers et al. compared changes in IGF1, fat oxidation, and protein metabolism in hypopituitary women on GH treatment during oral and transdermal administration (113). GH treatment significantly increased IGF1 levels in a stepwise, dose-dependent manner; however, mean IGF1 levels were significantly lower during oral estrogen at each $\mathrm{GH}$ dose.

Gender-related changes in body composition in response to GH replacement treatment in hypopituitary adults have been consistently observed from investigators regardless of the body composition techniques used. Johannsson et al. (117) observed that the increases in fat-free mass and total body water were more marked in men than women, as was the reduction in total body fat. In a placebo-controlled 9-month trial, Burman et al. (118) observed that GH treatment induced a greater reduction in the proportion of total body fat and in abdominal fat mass in men than women, as estimated by dual-energy X-ray absorptiometry. A large prospective study reported a progressive separation in fat mass, body nitrogen, and body potassium (indirect measures of body protein and cell mass respectively) between men and women treated for up to 5 years with $\mathrm{GH}$ indicating a degree of $\mathrm{GH}$ resistance in women $(119,120)$.

In addition, oral estrogen induced protein synthesis and secretion from the liver with increased levels of systemic inflammatory markers such as CRP (112). This together with the observation that oral estrogen, and not transdermal, attenuates the protein anabolic and lipid utilization effects of GH (112) might explain in part the reduced efficacy of GH treatment in hypopituitary women. It may also explain some previous observations that women seem to have a larger cardiovascular burden in the untreated GHD state than men (121) with more adverse lipid profile and more marked abdominal obesity in particular (122).

The data obtained from the KIMS database seem to support this hypothesis (123). The majority of women of fertile years with hypopituitarism within KIMS takes oral estrogen replacement therapy. The waist-to-hip ratio was greater in women taking oral estrogens, again suggesting that oral estrogens reduce the action of $\mathrm{GH}$ on fat mass. In addition, women using the oral contraceptive had lower serum IGF1 levels and required twice the GH dose compared with patients receiving transdermal estradiol (123). Estrogen replacement by the oral route, therefore, aggravates existing metabolic and body compositional abnormalities of the GH-deficient state and results in a relative resistance to $\mathrm{GH}$ replacement therapy, at least in terms of the effects on serum IGF1.

Whether the regime of testosterone replacement affects the clinical feature of hypopituitarism in men is less studied. Untreated hypogonadism has, however, many similarities to adult GHD such as low BMD, LBM, and increased body fat mass (124). In hypophysectomized, castrated, male rats, testosterone administration does not increase serum levels of IGF1 or IGF1 gene expression in the liver (125). However, combined GH and testosterone treatment augments the serum IGF1 increase and the increase in extracellular water in response to $\mathrm{GH}$ alone, suggesting that testosterone enhances the effect of $\mathrm{GH}$ (126). This may to some degree explain some of the sexual dimorphism in response to $\mathrm{GH}$.

\section{Summary}

Replacement therapy of MPHD in hypopituitarism is complex. Many of the hormones do not have reliable biomarkers to monitor adequacy other than the 
hormone itself. Therefore, monitoring is based on dose traditions together with clinical evaluation of the individual patients and together with targeting the serum levels of the hormone being replaced within the normal range. Adequacy of replacement is, therefore, not easy to evaluate in an individual patient. GH replacement has on the other hand a unique position as a biomarker of its action; serum IGF1 allows for a more precise dose titration and treatment monitoring.

In this review, we have reviewed data suggesting that other replacement therapies and their regime clearly affect the clinical features associated with severe GHD in adults. Moreover, it is likely that this influences the outcome of adult patients with hypopituitarism. This seems to be most obvious for GC replacement therapy and the route of estrogen replacement in hypopituitary women. On the other hand, the few data available indicate that the severity of the clinical feature of IGHD and patients with MPHD do not differ suggesting the importance of untreated GHD only. There are also some important interactions between hormones that need to be considered when replacing hypopituitary patients. Some of those are well known such as the unmasking of adrenal insufficiency when commencing $\mathrm{T}_{4}$ treatment, and others are less well known such as the unmasking of adrenal insufficiency and central hypothyroidism when initiating GH replacement therapy.

The post-marketing surveillance database of adult GH replacement therapy has become a useful tool to unravel more unsolved questions in the hypopituitary patients such as the adequacy of current GC, $\mathrm{T}_{4}$, and sex steroid replacement therapy.

\section{Declaration of interest}

The authors declare that there is no conflict of interest that could be perceived as prejudicing the impartiality of the research reported. $\mathrm{G}$ Johannsson has equity in DuoCort $\mathrm{AB}$, is a member of the KIMS scientific advisory board, and has received lecture fees from Pfizer and Novo Nordisk. KIMS ${ }^{\circledR}$ is supported by Pfizer Inc. This paper forms part of a European Journal of Endocrinology supplement, supported by Pfizer Inc.

\section{References}

1 Carroll PV, Christ ER, Bengtsson B- $\AA$, Carlsson L, Christiansen JS, Clemmons D, Hintz R, Ho K, Laron Z, Sizonenko P, Sönksen PH, Tanaka T \& Thorner M. Growth hormone deficiency in adulthood and the effects of growth hormone replacement: a review. Journal of Clinical Endocrinology and Metabolism $1998 \mathbf{8 3}$ 382-395.

2 Cuneo RC, Salomon F, Wiles CM \& Sönksen PH. Skeletal muscle performance in adults with growth hormone deficiency. Hormone Research 199033 55-60.

3 Filipsson H \& Johannsson G. Management of glucocorticoid replacement in adult growth hormone deficiency. Hormone Research 200767 155-164.

4 Filipsson H, Monson JP, Koltowska-Häggström M, Mattsson A \& Johannsson G. The impact of glucocorticoid replacement regimens on metabolic outcome and comorbidity in hypopituitary patients. Journal of Clinical Endocrinology and Metabolism $2006913954-3961$.

5 Tomlinson JW, Holden N, Hills RK, Wheatley K, Clayton RN, Bates AS, Sheppard MC \& Stewart PM. Association between premature mortality and hypopituitarism. West Midlands Prospective Hypopituitary Study Group. Lancet 2001357 425-431.

6 Regal M, Paramo C, Sierra SM \& Garcia-Mayor RV. Prevalence and incidence of hypopituitarism in an adult Caucasian population in northwestern Spain. Clinical Endocrinology 2001 55 735-740.

7 Lindholm J \& Nielsen EH. Pituitary-gonadal axis: historical notes. Pituitary 200812 226-235.

8 Salomon F, Cuneo RC, Hesp R \& Sonksen PH. The effects of treatment with recombinant human growth hormone on body composition and metabolism in adults with growth hormone deficiency. New England Journal of Medicine 1989321 1797-1803.

9 Jorgensen JO, Pedersen SA, Laurberg P, Weeke J, Skakkebaek NE \& Christiansen JS. Effects of growth hormone therapy on thyroid function of growth hormone-deficient adults with and without concomitant thyroxine-substituted central hypothyroidism. Journal of Clinical Endocrinology and Metabolism 198969 $1127-1132$.

10 Rosén T \& Bengtsson B-A. Premature mortality due to cardiovascular diseases in hypopituitarism. Lancet 1990336 285-288.

11 Bulow B, Hagmar L, Mikoczy Z, Nordstrom CH \& Erfurth EM. Increased cerebrovascular mortality in patients with hypopituitarism. Clinical Endocrinology 199746 75-81.

12 Bates AS, Van't Hoff W, Jones PJ \& Clayton RN. The effect of hypopituitarism on life expectancy. Journal of Clinical Endocrinology and Metabolism 199681 1169-1172.

13 Svensson J, Bengtsson BA, Rosen T, Oden A \& Johannsson G. Malignant disease and cardiovascular morbidity in hypopituitary adults with or without growth hormone replacement therapy. Journal of Clinical Endocrinology and Metabolism $2004 \mathbf{8 9}$ 3306-3312.

14 Rosen T, Johannsson G, Johansson JO \& Bengtsson BA. Consequences of growth hormone deficiency in adults and the benefits and risks of recombinant human growth hormone treatment. A review paper. Hormone Research 199543 93-99.

15 Sesmilo G, Miller KK, Hayden D \& Klibanski A. Inflammatory cardiovascular risk markers in women with hypopituitarism. Journal of Clinical Endocrinology and Metabolism $2001 \mathbf{8 6}$ 5774-5781.

16 Carroll PV, Christ ER, Bengtsson BA, Carlsson L, Christiansen JS, Clemmons D, Hintz R, Ho K, Laron Z, Sizonenko P, Sonksen PH, Tanaka T \& Thorne M. Growth hormone deficiency in adulthood and the effects of growth hormone replacement: a review. Growth Hormone Research Society Scientific Committee. Journal of Clinical Endocrinology and Metabolism 199883 382-395.

17 Gotherstrom G, Bengtsson BA, Bosaeus I, Johannsson G \& Svensson J. A 10-year, prospective study of the metabolic effects of growth hormone replacement in adults. Journal of Clinical Endocrinology and Metabolism 200766.

18 Gotherstrom GE, Elbornsson M, Stibrant-Sunnerhagen K, Bengtsson B-A, Johannsson G \& Svensson J. Ten years of growth hormone $(\mathrm{GH})$ replacement normalizes muscle strength in $\mathrm{GH}$ deficient adults. Journal of Clinical Endocrinology and Metabolism 200994 809-816.

19 Koltowska-Häggström M, Mattsson AF, Monson JP, Kind P, Badia X, Casanueva FF, Busschbach J, Koppeschaar HP \& Johannsson G. Does long-term GH replacement therapy in hypopituitary adults with GH deficiency normalise quality of life? European Journal of Endocrinology 2006155 109-119.

20 Gibney J, Wallace JD, Spinks T, Schnorr L, Ranicar A, Cuneo RC, Lockhart S, Burnand KG, Salomon F, Sonksen PH \& RussellJones D. The effects of 10 years of recombinant human growth hormone $(\mathrm{GH})$ in adult $\mathrm{GH}$-deficient patients. Journal of Clinical Endocrinology and Metabolism $1999 \mathbf{8 4} 2596-2602$. 
21 Wirén L, Bengtsson B-Å \& Johannsson G. Beneficial effects of long-term GH replacement therapy on quality of life in adults with GH deficiency. Clinical Endocrinology 199848 613-620.

22 Abs R, Mattsson AF, Bengtsson BA, Feldt-Rasmussen U, Goth MI, Koltowska-Haggstrom M, Monson JP, Verhelst J \& Wilton P. Isolated growth hormone $(\mathrm{GH})$ deficiency in adult patients: baseline clinical characteristics and responses to $\mathrm{GH}$ replacement in comparison with hypopituitary patients. A sub-analysis of the KIMS database. Growth Hormone \& IGF Research 200515 349-359.

23 Ho KK. Consensus guidelines for the diagnosis and treatment of adults with GH deficiency II: a statement of the GH Research Society in association with the European Society for Pediatric Endocrinology, Lawson Wilkins Society, European Society of Endocrinology, Japan Endocrine Society, and Endocrine Society of Australia. European Journal of Endocrinology 2007 157 695-700.

24 Pekic S, Doknic M, Djurovic M, Damjanovic S, Petakov M, Miljic D, Dieguez C, Casanueva FF \& Popovic V. The influence of serum cortisol levels on growth hormone responsiveness to GH-releasing hormone plus GH-releasing peptide-6 in patients with hypocortisolism. Hormones 20032 243-249.

25 Andersen M, Stoving RK, Hangaard J, Petersen PH \& Hagen C. The effect of short-term cortisol changes on growth hormone responses to the pyridostigmine-growth-hormone-releasinghormone test in healthy adults and patients with suspected growth hormone deficiency. Clinical Endocrinology $1998 \mathbf{4 9}$ 241-249.

26 Tzanela M, Karavitaki N, Stylianidou C, Tsagarakis S \& Thalassinos NC. Assessment of GH reserve before and after successful treatment of adult patients with Cushing's syndrome. Clinical Endocrinology 200460 309-314.

27 Schmid C, Zwimpfer C, Brandle M, Krayenbuhl PA, Zapf J \& Wiesli P. Effect of thyroxine replacement on serum IGF-I, IGFBP-3 and the acid-labile subunit in patients with hypothyroidism and hypopituitarism. Clinical Endocrinology $2006 \mathbf{6 5}$ 706-711.

28 Brauman H, Smets P \& Corvilain J. Comparative study of growth hormone response to hypoglycemia in normal subjects and in patients with primary myxedema or hyperthyroidism before and after treatment. Journal of Clinical Endocrinology and Metabolism 197336 1162-1174.

29 Williams T, Maxon H, Thorner MO \& Frohman LA. Blunted growth hormone $(\mathrm{GH})$ response to GH-releasing hormone in hypothyroidism resolves in the euthyroid state. Journal of Clinical Endocrinology and Metabolism 198561 454-456.

30 Ramos-Dias JC, Yateman M, Camacho-Hubner C, Grossman A \& Lengyel AM. Low circulating IGF-I levels in hyperthyroidism are associated with decreased $\mathrm{GH}$ response to $\mathrm{GH}$-releasing hormone. Clinical Endocrinology $1995 \mathbf{4 3} 583-589$.

31 Miell JP, Taylor AM, Zini M, Maheshwari HG, Ross RJ \& Valcavi R. Effects of hypothyroidism and hyperthyroidism on insulin-like growth factors (IGFs) and growth hormone- and IGF-binding proteins. Journal of Clinical Endocrinology and Metabolism $1993 \mathbf{7 6}$ 950-955.

32 Burgess JA, Smith BR \& Merimee TJ. Growth hormone in thyrotoxicosis: effect of insulin-induced hypoglycemia. Journal of Clinical Endocrinology and Metabolism 196626 1257-1260.

33 Ramos-Dias JC, Pimentel-Filho F, Reis AF \& Lengyel AM. Different growth hormone $(\mathrm{GH})$ response to GH-releasing peptide and GH-releasing hormone in hyperthyroidism. Journal of Clinical Endocrinology and Metabolism 199681 1343-1346.

34 De Leo V, Lanzetta D, D'Antona D \& Danero S. Growth hormone secretion in premenopausal women before and after ovariectomy: effect of hormone replacement therapy. Fertility and Sterility 1993 $60268-271$.

35 Bondanelli M, Ambrosio MR, Margutti A, Franceschetti P, Zatelli MC \& degli Uberti EC. Activation of the somatotropic axis by testosterone in adult men: evidence for a role of hypothalamic growth hormone-releasing hormone. Neuroendocrinology 200377 380-387.
36 Mukherjee A, Ryder WD, Jostel A \& Shalet SM. Prolactin deficiency is independently associated with reduced insulin-like growth factor I status in severely growth hormone-deficient adults. Journal of Clinical Endocrinology and Metabolism 200691 2520-2525.

37 Beentjes JA, Tjeerdsma G, Sluiter WJ \& Dullaart RP. Divergence between growth hormone responses to insulin-induced hypoglycaemia and growth hormone-releasing hormone in patients with non-functioning pituitary macroadenomas and hyperprolactinaemia. Clinical Endocrinology 199645 391-398.

38 Wake DJ, Rask E, Livingstone DE, Soderberg S, Olsson T \& Walker BR. Local and systemic impact of transcriptional up-regulation of 11 beta-hydroxysteroid dehydrogenase type 1 in adipose tissue in human obesity. Journal of Clinical Endocrinology and Metabolism 200388 3983-3988.

39 Paulsen SK, Pedersen SB, Jorgensen JO, Fisker S, Christiansen JS, Flyvbjerg A \& Richelsen B. Growth hormone (GH) substitution in GH-deficient patients inhibits 11beta-hydroxysteroid dehydrogenase type 1 messenger ribonucleic acid expression in adipose tissue. Journal of Clinical Endocrinology and Metabolism 200691 1093-1098.

40 Gelding SV, Taylor NF, Wood PJ, Noonan K, Weaver JU, Wood DF \& Monson JP. The effect of growth hormone replacement therapy on cortisol-cortisone interconversion in hypopituitary adults: evidence for growth hormone modulation of extrarenal 11 beta-hydroxysteroid dehydrogenase activity. Clinical Endocrinology 199848 153-163.

41 Weaver JU, Thaventhiran L, Noonan K, Burrin JM, Taylor NF, Norman MR \& Monson JP. The effect of growth hormone replacement on cortisol metabolism and glucocorticoid sensitivity in hypopituitary adults. Clinical Endocrinology $1994 \mathbf{4 1}$ 639-648.

42 Swords FM, Carroll PV, Kisalu J, Wood PJ, Taylor NF \& Monson JP. The effects of growth hormone deficiency and replacement on glucocorticoid exposure in hypopituitary patients on cortisone acetate and hydrocortisone replacement. Clinical Endocrinology $200359613-620$.

43 Giavoli C, Libe R, Corbetta S, Ferrante E, Lania A, Arosio M, Spada A \& Beck-Peccoz P. Effect of recombinant human growth hormone $(\mathrm{GH})$ replacement on the hypothalamic-pituitaryadrenal axis in adult GH-deficient patients. Journal of Clinical Endocrinology and Metabolism 200489 5397-5401.

44 Diederich S, Eigendorff E, Burkhardt P, Quinkler M, BumkeVogt C, Rochel M, Seidelmann D, Esperling P, Oelkers W \& Bahr V. 11Beta-hydroxysteroid dehydrogenase types 1 and 2: an important pharmacokinetic determinant for the activity of synthetic mineralo- and glucocorticoids. Journal of Clinical Endocrinology and Metabolism 200287 5695-5701.

45 Plotz CM, Knowlton AI \& Ragan C. The natural history of Cushings syndrome. American Journal of Medicine 195213 597-614.

46 Lukert BP \& Raisz LG. Glucocorticoid-induced osteoporosis: pathogenesis and management. Annals of Internal Medicine $1990112352-364$.

47 Mason AS, Meade TW, Lee JA \& Morris JN. Epidemiological and clinical picture of Addison's disease. Lancet 19682 744-747.

48 Mills JL, Schonberger LB, Wysowski DK, Brown P, Durako SJ, Cox C, Kong F \& Fradkin JE. Long-term mortality in the United States cohort of pituitary-derived growth hormone recipients. Journal of Pediatric 2004144 430-436.

49 Bergthorsdottir R, Leonsson-Zachrisson M, Oden A \& Johannsson G. Premature mortality in patients with Addison's disease: a population-based study. Journal of Clinical Endocrinology and Metabolism 200691 4849-4853.

50 Bensing S, Brandt L, Tabaroj F, Sjoberg O, Nilsson B, Ekbom A, Blomqvist P \& Kampe O. Increased death risk and altered cancer incidence pattern in patients with isolated or combined autoimmune primary adrenocortical insufficiency. Clinical Endocrinology $200869697-704$. 
51 Esteban NV, Loughlin T, Yergey AL, Zawadzki JK, Booth JD, Winterer JC \& Loriaux DL. Daily cortisol production rate in man determined by stable isotope dilution/mass spectrometry. Journal of Clinical Endocrinology and Metabolism 199172 39-45.

52 Kraan GP, Dullaart RP, Pratt JJ, Wolthers BG, Drayer NM \& De Bruin R. The daily cortisol production reinvestigated in healthy men. The serum and urinary cortisol production rates are not significantly different. Journal of Clinical Endocrinology and Metabolism $1998 \mathbf{8 3}$ 1247-1252.

53 Besser GM \& Jeffcoate WJ. Endocrine and metabolic diseases. Adrenal diseases. BMJ 19761 448-451.

54 Howlett TA. An assessment of optimal hydrocortisone replacement therapy. Clinical Endocrinology 199746 263-268.

55 Peacey SR, Guo CY, Robinson AM, Price A, Giles MA, Eastell R \& Weetman AP. Glucocorticoid replacement therapy: are patients over treated and does it matter? Clinical Endocrinology $1997 \mathbf{4 6}$ 255-261.

56 Barbetta L, Dall'Asta C, Re T, Libe R, Costa E \& Ambrosi B. Comparison of different regimens of glucocorticoid replacement therapy in patients with hypoadrenalism. Journal of Endocrinological Investigation $2005 \mathbf{2 8} 632-637$.

57 Crown A \& Lightman S. Why is the management of glucocorticoid deficiency still controversial: a review of the literature. Clinical Endocrinology 200563 483-492.

58 Zelissen PM, Croughs RJ, van Rijk PP \& Raymakers JA. Effect of glucocorticoid replacement therapy on bone mineral density in patients with Addison disease. Annals of Internal Medicine 1994 120 207-210.

59 Wichers M, Springer W, Bidlingmaier F \& Klingmuller D. The influence of hydrocortisone substitution on the quality of life and parameters of bone metabolism in patients with secondary hypocortisolism. Clinical Endocrinology 199950 759-765.

60 al-Shoumer KA, Beshyah SA, Niththyananthan R \& Johnston DG. Effect of glucocorticoid replacement therapy on glucose tolerance and intermediary metabolites in hypopituitary adults. Clinical Endocrinology 199542 85-90.

61 Dunne FP, Elliot P, Gammage MD, Stallard T, Ryan T, Sheppard MC \& Stewart PM. Cardiovascular function and glucocorticoid replacement in patients with hypopituitarism. Clinical Endocrinology 199543 623-629.

62 McConnell EM, Bell PM, Ennis C, Hadden DR, McCance DR, Sheridan B \& Atkinson AB. Effects of low-dose oral hydrocortisone replacement versus short-term reproduction of physiological serum cortisol concentrations on insulin action in adult-onset hypopituitarism. Clinical Endocrinology $2002 \mathbf{5 6}$ 195-201.

63 Danilowicz K, Bruno OD, Manavela M, Gomez RM \& Barkan A. Correction of cortisol overreplacement ameliorates morbidities in patients with hypopituitarism: a pilot study. Pituitary 200811 279-285.

64 Hahner S, Loeffler M, Fassnacht M, Weismann D, Koschker AC, Quinkler M, Decker O, Arlt W \& Allolio B. Impaired subjective health status in 256 patients with adrenal insufficiency on standard therapy based on cross-sectional analysis. Journal of Clinical Endocrinology and Metabolism 200792 3912-3922.

65 Lovas K, Loge JH \& Husebye ES. Subjective health status in Norwegian patients with Addison's disease. Clinical Endocrinology $2002 \mathbf{5 6} 581-588$

66 Gurnell EM, Hunt PJ, Curran SE, Conway CL, Pullenayegum EM, Huppert FA, Compston JE, Herbert J \& Chatterjee VK. Long-term DHEA replacement in primary adrenal insufficiency: a randomized, controlled trial. Journal of Clinical Endocrinology and Metabolism 200893 400-409.

67 Lovas K \& Husebye ES. Continuous subcutaneous hydrocortisone infusion in Addison's disease. European Journal of Endocrinology 2007157 109-112.

68 Persani L, Ferretti E, Borgato S, Faglia G \& Beck-Peccoz P. Circulating thyrotropin bioactivity in sporadic central hypothyroidism. Journal of Clinical Endocrinology and Metabolism 200085 3631-3635.
69 Persani L. Hypothalamic thyrotropin-releasing hormone and thyrotropin biological activity. Thyroid 1998 8 941-946.

70 Patel YC \& Burger HG. Serum thyrotropin (TSH) in pituitary and-or hypothalamic hypothyroidism: normal or elevated basal levels and paradoxical responses to thyrotropin-releasing hormone. Journal of Clinical Endocrinology and Metabolism 1973 37 190-196.

71 Andersen S, Pedersen KM, Bruun NH \& Laurberg P. Narrow individual variations in serum $\mathrm{T}(4)$ and $\mathrm{T}(3)$ in normal subjects: a clue to the understanding of subclinical thyroid disease. Journal of Clinical Endocrinology and Metabolism $2002 \mathbf{8 7}$ 1068-1072.

72 Yamakita N, Komaki T, Takao T, Murai T, Hashimoto K \& Yasuda K. Usefulness of thyrotropin (TSH)-releasing hormone test and nocturnal surge of TSH for diagnosis of isolated deficit of TSH secretion. Journal of Clinical Endocrinology and Metabolism 200186 1054-1060.

73 Rose SR, Lustig RH, Pitukcheewanont P, Broome DC, Burghen GA, Li H, Hudson MM, Kun LE \& Heideman RL. Diagnosis of hidden central hypothyroidism in survivors of childhood cancer. Journal of Clinical Endocrinology and Metabolism 199984 4472-4479.

74 Agha A, Walker D, Perry L, Drake WM, Chew SL, Jenkins PJ, Grossman AB \& Monson JP. Unmasking of central hypothyroidism following growth hormone replacement in adult hypopituitary patients. Clinical Endocrinology $20076672-77$.

75 Alexopoulou O, Beguin C, De Nayer P \& Maiter D. Clinical and hormonal characteristics of central hypothyroidism at diagnosis and during follow-up in adult patients. European Journal of Endocrinology 2004150 1-8.

76 Lania A, Persani L \& Beck-Peccoz P. Central hypothyroidism. Pituitary 200811 181-186.

77 Ferretti E, Persani L, Jaffrain-Rea ML, Giambona S, Tamburrano G \& Beck-Peccoz P. Evaluation of the adequacy of levothyroxine replacement therapy in patients with central hypothyroidism. Journal of Clinical Endocrinology and Metabolism 199984 924-929.

78 Porretti S, Giavoli C, Ronchi C, Lombardi G, Zaccaria M, Valle D, Arosio M \& Beck-Peccoz P. Recombinant human GH replacement therapy and thyroid function in a large group of adult GH-deficient patients: when does L-T(4) therapy become mandatory? Journal of Clinical Endocrinology and Metabolism $2002872042-2045$.

79 Losa M, Scavini M, Gatti E, Rossini A, Madaschi S, Formenti I, Caumo A, Stidley CA \& Lanzi R. Long-term effects of growth hormone replacement therapy on thyroid function in adults with growth hormone deficiency. Thyroid $2008 \mathbf{1 8}$ 1249-1254.

80 Hubina E, Mersebach H, Rasmussen AK, Juul A, Sneppen SB, Goth MI \& Feldt-Rasmussen U. Effect of growth hormone replacement therapy on pituitary hormone secretion and hormone replacement therapies in GHD adults. Hormone Research $200461211-217$.

81 Giavoli C, Porretti S, Ferrante E, Cappiello V, Ronchi CL, Travaglini P, Epaminonda P, Arosio M \& Beck-Peccoz P. Recombinant hGH replacement therapy and the hypothalamus-pituitary-thyroid axis in children with GH deficiency: when should we be concerned about the occurrence of central hypothyroidism? Clinical Endocrinology 200359 806-810.

82 Grubeck-Loebenstein B, Vierhapper H, Waldhausl W \& Nowotny P. Thyroid function in adrenocortical insufficiency during withdrawal and re-administration of glucocorticoid substitution. Acta Endocrinologica 1983103 254-258.

83 Abdullatif HD \& Ashraf AP. Reversible subclinical hypothyroidism in the presence of adrenal insufficiency. Endocrine Practice 2006 12572.

84 Caron PJ, Nieman LK, Rose SR \& Nisula BC. Deficient nocturnal surge of thyrotropin in central hypothyroidism. Journal of Clinical Endocrinology and Metabolism $1986 \mathbf{6 2} 960-964$. 
85 Rose SR, Manasco PK, Pearce S \& Nisula BC. Hypothyroidism and deficiency of the nocturnal thyrotropin surge in children with hypothalamic-pituitary disorders. Journal of Clinical Endocrinology and Metabolism 199070 1750-1755.

86 Patel YC, Alford FP \& Burger HG. The 24-hour plasma thyrotrophin profile. Clinical Science 197243 71-77.

87 Vanhaelst L, Van Cauter E, Degaute JP \& Golstein J. Circadian variations of serum thyrotropin levels in man. Journal of Clinical Endocrinology and Metabolism 197235 479-482.

88 Weeke J. Circadian variation of the serum thyrotropin level in normal subjects. Scandinavian Journal of Clinical and Laboratory Investigation 197331 337-342.

89 Romijn JA \& Wiersinga WM. Decreased nocturnal surge of thyrotropin in nonthyroidal illness. Journal of Clinical Endocrinology and Metabolism 199070 35-42.

90 Monig H, Stracke L, Arendt T \& Kloehn S. Blunted nocturnal TSH surge does not indicate central hypothyroidism in patients after pituitary surgery. Experimental and Clinical Endocrinology and Diabetes 1999107 89-92.

91 Bartalena L, Martino E, Brandi LS, Falcone M, Pacchiarotti A, Ricci C, Bogazzi F, Grasso L, Mammoli C \& Pinchera A. Lack of nocturnal serum thyrotropin surge after surgery. Journal of Clinical Endocrinology and Metabolism $1990 \quad \mathbf{7 0}$ 293-296.

92 Romijn JA, Adriaanse R, Brabant G, Prank K, Endert E \& Wiersinga WM. Pulsatile secretion of thyrotropin during fasting: a decrease of thyrotropin pulse amplitude. Journal of Clinical Endocrinology and Metabolism 199070 1631-1636.

93 Weeke J \& Laurberg P. Diural TSH variations in hypothyroidism. Journal of Clinical Endocrinology and Metabolism 1976 43 32-37.

94 Faglia G, Beck-Peccoz P, Ferrari C, Ambrosi B, Spada A, Travaglini P \& Paracchi S. Plasma thyrotropin response to thyrotropin-releasing hormone in patients with pituitary and hypothalamic disorders. Journal of Clinical Endocrinology and Metabolism 197337 595-601.

95 Faglia G. The clinical impact of the thyrotropin-releasing hormone test. Thyroid $1998 \mathbf{8} 903-908$.

96 Hartoft-Nielsen ML, Lange M, Rasmussen AK, Scherer S, Zimmermann-Belsing $\mathrm{T}$ \& Feldt-Rasmussen U. Thyrotropinreleasing hormone stimulation test in patients with pituitary pathology. Hormone Research 200461 53-57.

97 Auernhammer CJ \& Vlotides G. Anterior pituitary hormone replacement therapy - a clinical review. Pituitary 200710 1-15.

98 Querido A \& Stanbury JB. Primary and secondary hypothyroidism. Journal of Clinical Endocrinology and Metabolism $1950 \mathbf{1 0}$ $1192-1201$

99 Stanley MM \& Astwoor EB. The response of the thyroid gland in normal human subjects to the administration of thyrotropin as shown by studies with $\mathrm{I}^{131}$. Endocrinology 1949 44 49-60.

100 Robbins J. Pharmacology of bovine and human thyrotropin: an historical perspective. Thyroid 19999 451-453.

101 Palmieri EA, Fazio S, Lombardi G \& Biondi B. Subclinical hypothyroidism and cardiovascular risk: a reason to treat? Treatments in Endocrinology 20043 233-244.

102 Fatourechi V. Upper limit of normal serum thyroid-stimulating hormone: a moving and now an aging target? Journal of Clinical Endocrinology and Metabolism 200792 4560-4562.

103 Lehmke J, Bogner U, Felsenberg D, Peters H \& Schleusener H. Determination of bone mineral density by quantitative computed tomography and single photon absorptiometry in subclinical hyperthyroidism: a risk of early osteopaenia in post-menopausal women. Clinical Endocrinology 199236 511-517.

104 Kalmijn S, Mehta KM, Pols HA, Hofman A, Drexhage HA \& Breteler MM. Subclinical hyperthyroidism and the risk of dementia. The Rotterdam Study. Clinical Endocrinology 2000 53 733-737.

105 Smit JW, Eustatia-Rutten CF, Corssmit EP, Pereira AM, Frolich M, Bleeker GB, Holman ER, van der Wall EE, Romijn JA \& Bax JJ. Reversible diastolic dysfunction after long-term exogenous subclinical hyperthyroidism: a randomized, placebo-controlled study. Journal of Clinical Endocrinology and Metabolism 200590 6041-6047.

106 Auer J, Scheibner P, Mische T, Langsteger W, Eber O \& Eber B. Subclinical hyperthyroidism as a risk factor for atrial fibrillation. American Heart Journal 2001142 838-842.

107 Parle JV, Maisonneuve P, Sheppard MC, Boyle P \& Franklyn JA. Prediction of all-cause and cardiovascular mortality in elderly people from one low serum thyrotropin result: a 10-year cohort study. Lancet $20013 \mathbf{3 8} 861-865$.

108 Rose SR. Isolated central hypothyroidism in short stature. Pediatric Research 199538 967-973.

109 Carrozza V, Csako G, Yanovski JA, Skarulis MC, Nieman L, Wesley R \& Pucino F. Levothyroxine replacement therapy in central hypothyroidism: a practice report. Pharmacotherapy 1999 19 349-355.

110 Shimon I, Cohen O, Lubetsky A \& Olchovsky D. Thyrotropin suppression by thyroid hormone replacement is correlated with thyroxine level normalization in central hypothyroidism. Thyroid $200212823-827$.

111 Slawik M, Klawitter B, Meiser E, Schories M, Zwermann O, Borm K, Peper M, Lubrich B, Hug MJ, Nauck M, Olschewski M, Beuschlein F \& Reincke M. Thyroid hormone replacement for central hypothyroidism: a randomized controlled trial comparing two doses of thyroxine $\left(\mathrm{T}_{4}\right)$ with a combination of $\mathrm{T}_{4}$ and triiodothyronine. Journal of Clinical Endocrinology and Metabolism $2007924115-4122$.

112 Leung KC, Johannsson G, Leong GM \& Ho KK. Estrogen regulation of growth hormone action. Endocrine Reviews 2004 25 693-721.

113 Wolthers T, Hoffman DM, Nugent AG, Duncan MW, Umpleby M \& Ho KK. Oral estrogen antagonizes the metabolic actions of growth hormone in growth hormone-deficient women. American Journal of Physiology. Endocrinology and Metabolism 2001281 E1191-E1196.

114 Svensson J, Johannsson G \& Bengtsson B-Å. Insulin-like growth factor-I in growth hormone-deficient adults: relationship to population-based normal values, body composition and insulin tolerance test. Clinical Endocrinology 199746 579-586.

115 Gibney J, Johannsson G, Leung KC \& Ho KK. Comparison of the metabolic effects of raloxifene and oral estrogen in postmenopausal and growth hormone-deficient women. Journal of Clinical Endocrinology and Metabolism 200590 3897-3903.

116 Cook DM, Ludlam WH \& Cook MB. Route of estrogen administration helps to determine growth hormone (GH) replacement dose in $\mathrm{GH}$-deficient adults. Journal of Clinical Endocrinology and Metabolism 199984 3956-3960.

117 Johannsson G, Bjarnason R, Bramnert M, Carlsson LMS, Degerblad M, Manhem P, Rosén T, Thorén M \& Bengtsson B-A. The individual responsiveness to growth hormone $(\mathrm{GH})$ treatment in GH-deficient adults is dependent on the level of $\mathrm{GH}$ binding protein, body mass index, age and gender. Journal of Clinical Endocrinology and Metabolism $1996 \mathbf{8 1}$ 1575-1581.

118 Burman P, Johansson AG, Siegbahn A, Vessby B \& Karlsson FA. Growth hormone (GH)-deficient men are more responsive to GH replacement therapy than women. Journal of Clinical Endocrinology and Metabolism 199782 550-555.

119 Gotherstrom G, Svensson J, Koranyi J, Alpsten M, Bosaeus I, Bengtsson B \& Johannsson G. A prospective study of 5 years of GH replacement therapy in GH-deficient adults: sustained effects on body composition, bone mass, and metabolic indices. Journal of Clinical Endocrinology and Metabolism $2001 \mathbf{8 6}$ 4657-4665.

120 Johannsson G, Grimby G, Stibrant Sunnerhagen K \& Bengtsson B-Å. Two years of growth hormone (GH) treatment increases isometric and isokinetic muscle strength in GH-deficient adults. Journal of Clinical Endocrinology and Metabolism 1997 82 2877-2884. 
121 Beshyah SA \& Johnston DG. Cardiovascular disease and risk factors in adults with hypopituitarism. Clinical Endocrinology $1999501-15$.

122 Johansson J-O, Fowelin J, Landin K, Lager I \& Bengtsson B-Å. Growth hormone-deficient adults are insulin-resistant. Metabolism $1995 \mathbf{4 4} 1126-1129$.

123 Mah PM, Webster J, Jonsson P, Feldt-Rasmussen U, KoltowskaHäggström M \& Ross RJ. Estrogen replacement in women of fertile years with hypopituitarism. Journal of Clinical Endocrinology and Metabolism 200590 5964-5969.

124 Mauras N, Hayes V, Welch S, Rini A, Helgeson K, Dokler M, Veldhuis JD \& Urban RJ. Testosterone deficiency in young men: marked alterations in whole body protein kinetics, strength, and adiposity. Journal of Clinical Endocrinology and Metabolism 1998 83 1886-1892.
125 Phillip M, Palese T, Hernandez ER, Roberts CT Jr, LeRoit D \& Kowarski AA. Effect of testosterone on insulin-like growth factor-I (IGF-I) and IGF-I receptor gene expression in the hypophysectomized rat. Endocrinology $19921302865-2870$.

126 Johannsson G, Gibney J, Wolthers T, Leung KC \& Ho KK. Independent and combined effects of testosterone and growth hormone on extracellular water in hypopituitary men. Journal of Clinical Endocrinology and Metabolism 200590 3989-3994.

Received 22 July 2009

Accepted 30 July 2009 